\title{
ASSESSMENT OF SELECTED TECHNICAL PARAMETERS OF SOYA SEEDS OIL PRESSING PROCESS
}

\author{
Marian Panasiewicz*, Jacek Mazur, Rafał Nadulski, Paweł Sobczak, Kazimierz Zawiślak, \\ Zbigniew Kobus
}

Department of Engineering and Food Machines, University of Natural Sciences in Lublin

*Corresponding author: e-mail: marian.panasiewicz@up.lublin.pl

\begin{tabular}{|c|c|}
\hline ARTICLE INFO & ABSTRACT \\
\hline $\begin{array}{l}\text { Article history: } \\
\text { Received: March } 2017 \\
\text { Received in the revised form: } \\
\text { May } 2017 \\
\text { Accepted: June } 2017\end{array}$ & $\begin{array}{l}\text { The objective of the paper was to determine the impact of the value of } \\
\text { the oil pressing pressure with the cold pressing method in a screw } \\
\text { press on the pressing course and performance. Varied values of pres- } \\
\text { sure were obtained through the use of three replaceable attachments of } \\
\text { the pressing unit with a varied diameter of the outlet conduit }\left(\phi_{1}=2\right.\end{array}$ \\
\hline $\begin{array}{l}\text { Key words: } \\
\text { oil pressing, } \\
\text { soya seeds, } \\
\text { parameters and conditions of the } \\
\text { process, } \\
\text { performance }\end{array}$ & $\begin{array}{l}\left.\mathrm{mm}, \phi_{2}=4 \mathrm{~mm} \text { and } \phi_{3}=6 \mathrm{~mm}\right) \text {. The soya oil pressing process perfor- } \\
\text { mance was determined in relation to the applied attachment and the } \\
\text { soya cultivar. Seeds of } 7 \text { Polish non-genetically modified soya culti- } \\
\text { vars constituted research material. It was proved that both variable } \\
\text { pressure values and the used soya cultivars have impact on the press- } \\
\text { ing performance. Based on the analysis of the obtained research } \\
\text { results it was proved that varied technical parameters and soya culti- } \\
\text { vars influence both the process performance and the remaining param- } \\
\text { eters and pressing conditions. }\end{array}$ \\
\hline
\end{tabular}

\section{Introduction}

Soya is one of the most precious plants cultivated around the world. Its significance is related to the chemical composition of seeds which include between 18 and $22 \%$ of oil with a considerable content of unsaturated fatty acids and between 33 and $45 \%$ of protein with a good amino-acid balance. High concentration of the above components is very significant in feeding of both people and animals (Zawadzki, 2010; Sikorski, 2007; Barowicz, 2008).

Poland is one of the countries with great traditions related to multiple use of oil plants (Baler, 2013; Nowak, 2011). In recent years in Poland we have observed considerable interest in newly cultivated genetically unmodified Polish soya cultivars. Seeds of this plant constitute a valuable processing raw material mainly used as a component of industrial fodders with a high content of protein and for production of oils designed for consumption purposes (Sikorski, 2007; Barowicz, 2008; Flowers et al, 2008). One of the research trends is obtaining soya oil with a deep pressing method, which contrary to a technology based on the extrusion method, allows obtaining oils with a high content of natural antioxidants and maintaining other compounds favourable for health (Laska et al., 2012; Boros, 2002; Budzyński and Zając, 2010; Dłużewska and Krygier, 2015). Oil produced from genetically unmodified soya seeds is particularly valuable. Oil obtained by means of the pressing pro- 
cess of whole and husked soya seeds is a great plant product and constitutes a valuable source of unsaturated fatty acids (Domaracka, 2016; Flowers et al., 2008).

\section{The objective and the scope of research}

The objective of the paper was to assess the impact of the selected factors on the course and amount of pressed soya oil from 7 various soya cultivars. The soya oil pressing process performance in the screw press was determined in relation to the applied three attachments of a varied diameter and soya cultivars. During the research, the amount of the obtained oil from each variety, pressing time and temperature were measured.

The scope of the research:

- seeds preparation time (cleaning, husking),

- oil pressing with heads of a varied diameter of openings,

- measurement of the selected parameters of the process and the assessment of performance and its course.

\section{Methodology of research and test devices}

Seeds of 7 Polish genetically unmodified soya cultivars modified were the material for research. The selected cultivars were obtained by means of mechanical harvesting from an East Poland grower. The selected cultivars are not genetically modified; presently work is carried out to register them and domesticate on the Polish soil. Seeds of seven soya cultivars were used in the research: Annushka, Marta, Mavka, Merlin, Pollux, Protina and Syrelia. Presently, only one of them - Mavka is registered in the National Register of Cultivars. The selection of cultivars was justified based on the positive assessment and data concerning a technological value of seeds presented both by growers and the processing sector.

The whole cycle of the research aimed at obtaining a maximum amount of the mechanically pressed oil from 1000 gram samples of non-husked and husked seeds in $n=5$ iterations. Oils were pressed with the use of a laboratory screw press (Figure 2,3).

a)

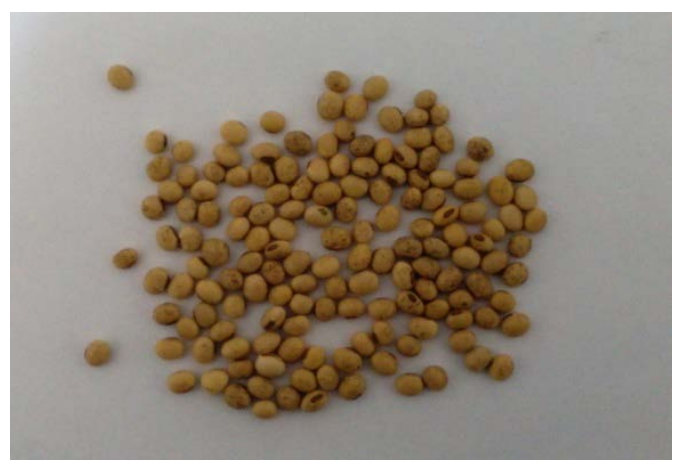

b)

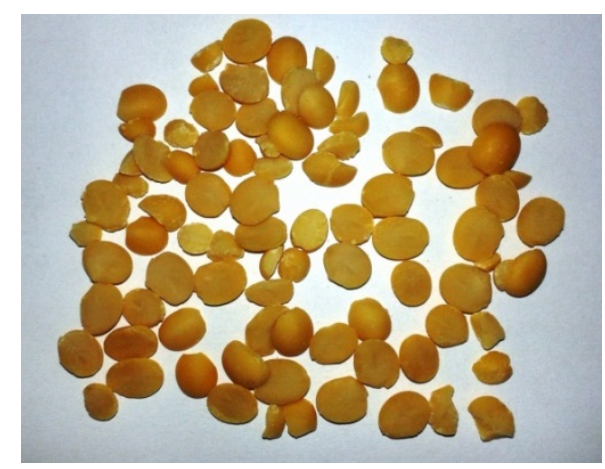

Figure 1. Soya seeds of an exemplary cultivar: a) non-husked, b) husked 


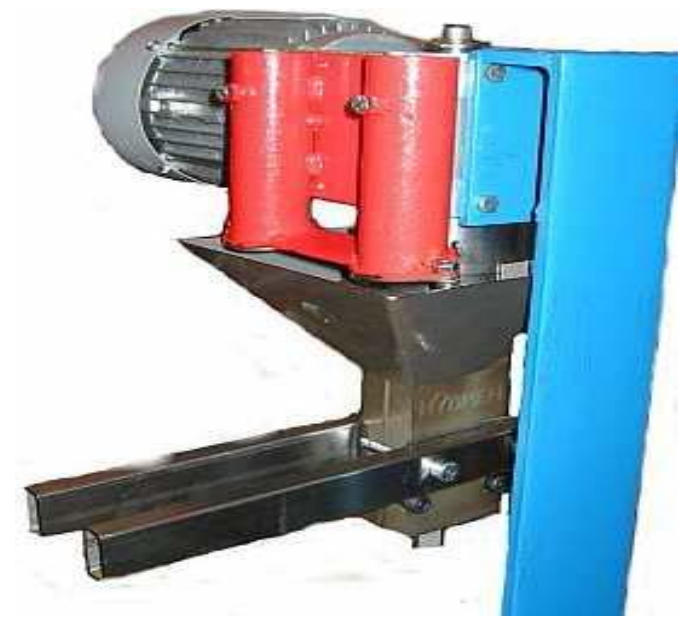

Figure 2. HYBREN screw press
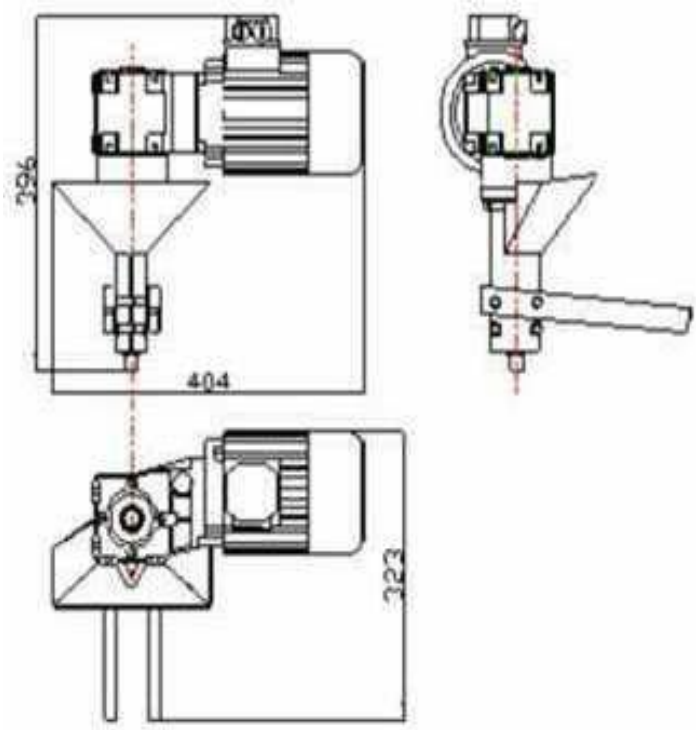

Figure 3. Schematic representation of press in three projections

Varied values of pressure were obtained through the use of three exchangeable attachments of the pressing unit with a varied diameter of the outlet conduit i.e. $\left(\phi_{1}=2 \mathrm{~mm}\right.$, $\phi_{2}=4 \mathrm{~mm}$ and $\phi_{3}=6 \mathrm{~mm}$ ). 


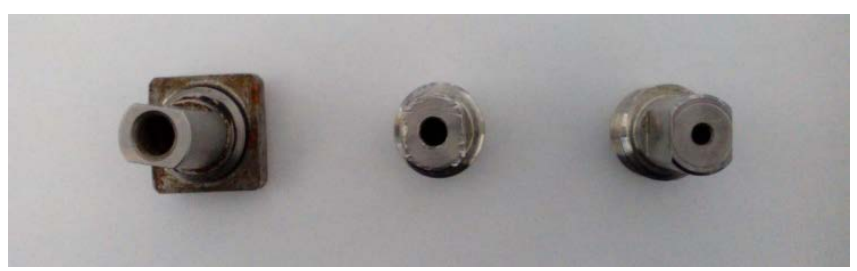

Figure 4. Replaceable heads of the screw press: (from the left), diameter $\phi_{3}=6 \mathrm{~mm}$ ), $\phi_{2}=4 \mathrm{~mm}$ and $\phi_{1}=2 \mathrm{~mm}$

Oil pressing performance was determined according to the formula:

$$
\mathrm{W}=\frac{\text { Oil weight }}{\text { Single sample weight }} \cdot 100 \%
$$

Single sample weight was $1000 \mathrm{~g}$.

\section{Research results and their analysis}

The research which was carried out and analysis of the obtained results allowed determination of the amount of mechanically pressed oil from seeds of each soya cultivar in relation to the applied parameters of the press (various diameters of the matrix openings) and initial treatment of seeds. This analysis confirms that the varied technical parameters resulting from the type of applied pressing heads and soya cultivars influence both the time course of the pressing process and its performance. Table 1 presents data concerning screw press performance during oil pressing from soya seeds in relation to the applied parameters of the process. Based on the analysis of the obtained research results, one may state that both variable pressure values and the used soya cultivars have a considerable impact on the oil pressing performance. Noticeable difference in the amount of pressed oil with regard to 3 dimensions of diameters of applied heads, 7 soya cultivars and initial treatment (nonhusked and husked seeds) were found. With regard to cultivars, the biggest amount of oil was obtained during oil pressing from Pollux and Mavka seeds. Performance of the process with a $\phi_{1}=2 \mathrm{~mm}$ head for non-husked seeds was respectively $7.13 \%$ and $6.79 \%$ and for the non-husked seeds of these cultivars it was respectively $11.01 \%$ and $9.81 \%$. With regard to the assessment of the pressing process course and its performance measured with the highest amount of the obtained oil, the most favourable effects were obtained for pressing with the use of a pressing head with the smallest diameter i.e. $\left(\phi_{1}=2 \mathrm{~mm}\right)$. Considerable differences of the process performance which was carried out in the same conditions was obtained for the group of husked and non-husked seeds. Removal of the fruit and seed coat (husk) leads to the increase of the amount of the obtained plant oil. It is related both to all cultivars and three applied pressing heads (Table 1). 
Assessment of selected technical...

Table 1.

Research results concerning performance of the press during pressing oil from non-husked and husked seeds of various soya cultivars and variable diameter of the applied pressing attachments

\begin{tabular}{|c|c|c|c|c|c|}
\hline \multicolumn{2}{|c|}{ Initial processing } & \multicolumn{2}{|c|}{ Non-husked soya } & \multicolumn{2}{|c|}{ Husked soya } \\
\hline $\begin{array}{l}\text { Soya } \\
\text { cultivars }\end{array}$ & $\begin{array}{c}\text { Head } \\
\text { diameter } \\
(\mathrm{mm})\end{array}$ & $\begin{array}{l}\text { Weight } \\
\text { of oil } \\
\text { (g) }\end{array}$ & $\begin{array}{c}\text { Press } \\
\text { performance } \\
(\%)\end{array}$ & $\begin{array}{l}\text { Weight } \\
\text { of oil } \\
\text { (g) }\end{array}$ & $\begin{array}{c}\text { Press } \\
\text { performance } \\
(\%)\end{array}$ \\
\hline Annushka & & 48.9 & 4.89 & 57.88 & 5.79 \\
\hline Marta & & 53.93 & 5.39 & 81.48 & 8.14 \\
\hline Mavka & & 67.92 & 6.79 & 98.80 & 9.88 \\
\hline Merlin & $\phi_{1}=2$ & 66.37 & 6.64 & 94.56 & 9.46 \\
\hline Pollux & & 71.38 & 7.14 & 110.12 & 11.01 \\
\hline Protina & & 17.5 & 1.75 & 20.6 & 2.06 \\
\hline Syrelia & & 47.4 & 4.74 & 71.44 & 7.14 \\
\hline Annushka & & 41.81 & 4.18 & 50.72 & 5.07 \\
\hline Marta & & 52.58 & 5.26 & 66.08 & 6.60 \\
\hline Mavka & & 65.52 & 6.55 & 101.52 & 10.15 \\
\hline Merlin & $\phi_{2}=4$ & 64.56 & 6.46 & 77.28 & 7.73 \\
\hline Pollux & & 70.5 & 7.05 & 107.2 & 10.72 \\
\hline Protina & & 14.7 & 1.47 & 18.04 & 1.80 \\
\hline Syrelia & & 47.85 & 4.78 & 43.36 & 4.34 \\
\hline Annushka & & 41.5 & 4.15 & 41 & 4.10 \\
\hline Marta & & 50.72 & 5.07 & 51.64 & 5.16 \\
\hline Mavka & & 66.72 & 6.67 & 93.84 & 9.38 \\
\hline Merlin & $\phi_{3}=6$ & 48.78 & 4.88 & 67.44 & 6.74 \\
\hline Pollux & & 67.4 & 6.74 & 94.15 & 9.41 \\
\hline Protina & & 14 & 1.40 & 15.16 & 1.52 \\
\hline Syrelia & & 40.98 & 4.09 & 42.12 & 4.21 \\
\hline Average & $\mathrm{x}$ & 51.46 & 5.15 & 63.77 & 6.38 \\
\hline
\end{tabular}

Figure 5 presents the scope of oil and pomace temperature in relation to the applied diameter of the pressing head opening. The highest average temperature of $71-72^{\circ} \mathrm{C}$ was reported in case of oil pressing with a head of the smallest diameter $\phi_{1}=2 \mathrm{~mm}$, and the lowest with the head of $\phi_{3}=6 \mathrm{~mm}$. The lowest diameter of the head opening, the highest compaction force and oil pressing force which causes increase of its temperature. 


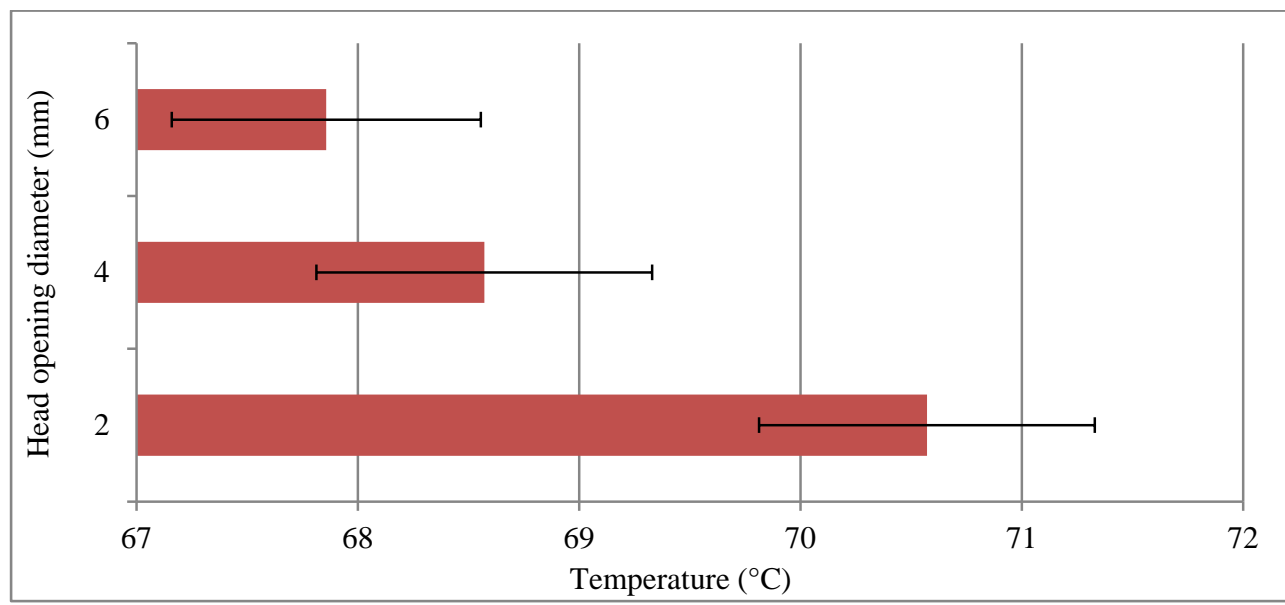

Figure 5. Average values of oil and pomace temperature with regard to the diameter of the head openings

With regard to the pressing time, it was proved that the longest average duration of the process took place when the head with the smallest head diameter was used i.e. $\phi_{1}=2 \mathrm{~mm}$. For the same mass of samples it was 587 seconds (Fig.6). In case of the remaining heads $\left(\phi_{2}=4 \mathrm{~mm}\right.$ i $\left.\phi_{3}=6 \mathrm{~mm}\right)$ the pressing time was considerably shorter and was within $538-540$ seconds.

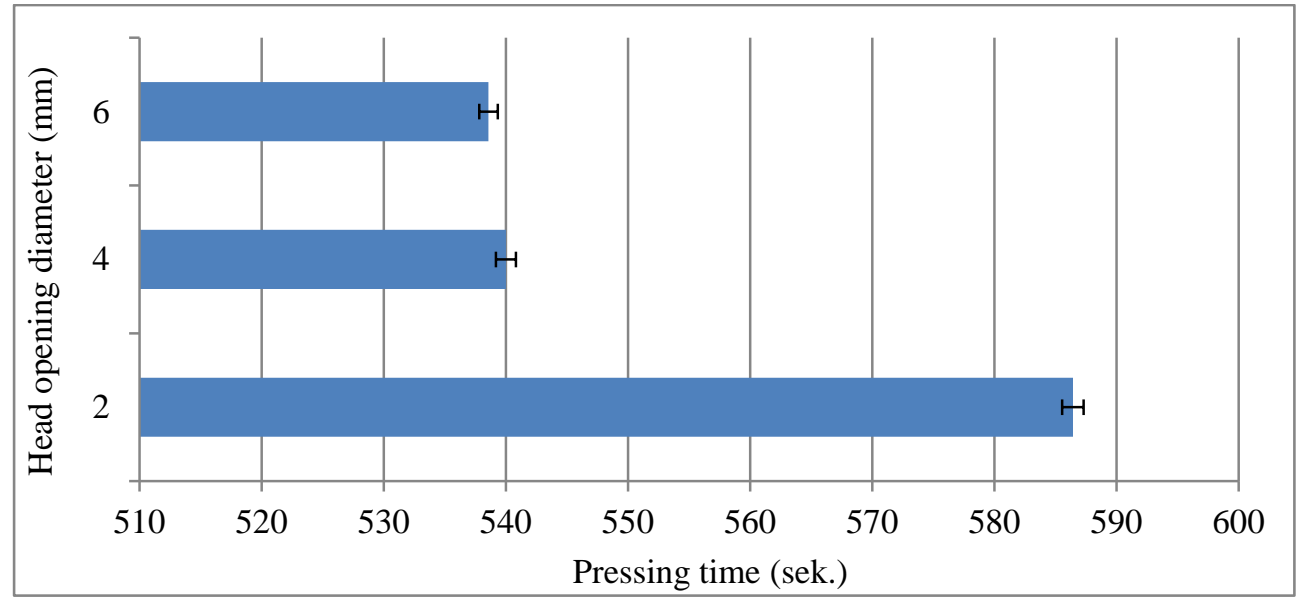

Figure 6. Average values of the pressing time with regard to the head opening diameter

Assessing the pressing process performance from the angle of the obtained amount of oil from the husked raw material of particular soya cultivars, it was stated that Pollux and Mavka cultivar were the most efficient. With the use of the pressing head the mass of oil of 
Assessment of selected technical...

$110.12 \mathrm{~g}$ and performance of $11.01 \%$ was obtained from non-husked Pollux seeds and for Mavka cultivar $98.8 \mathrm{~g}$ of oil with the performance of 9.88\% (Table 1 and Figure 7). The initial content of oil in seeds of these cultivars was respectively $20.8 \%$ and $20.3 \%$.

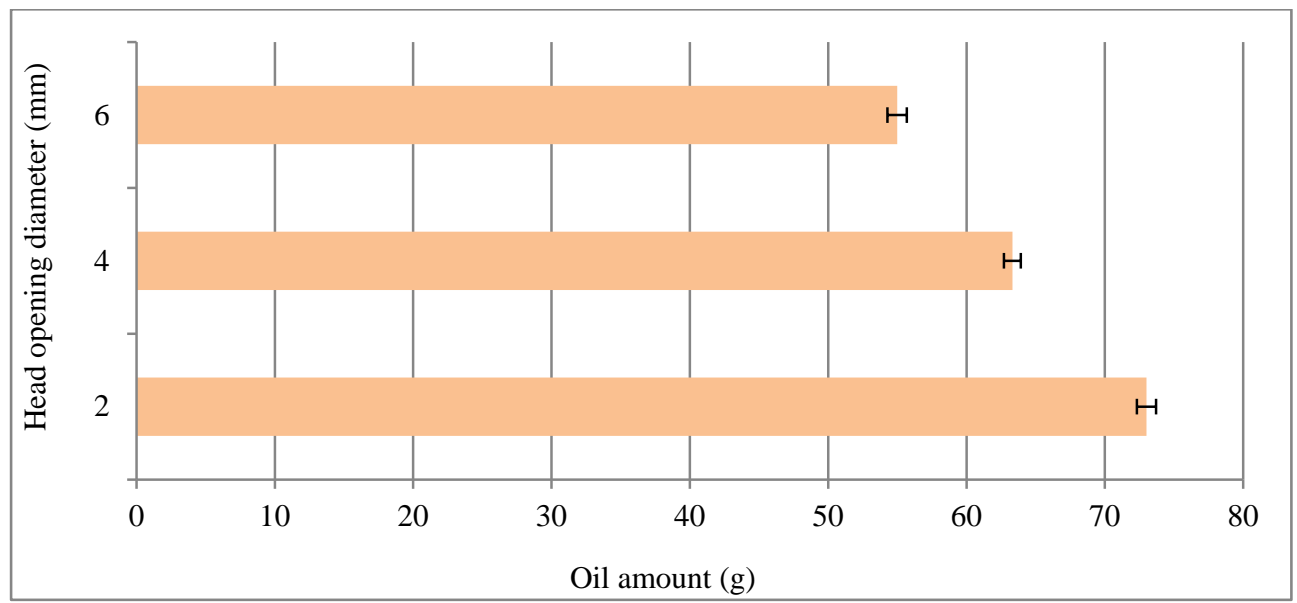

Figure 7. Average values of the amount of the obtained oil with regard to the diameter of the head openings

This trend was maintained with pressing seeds of these cultivars on all heads of a device. Protina was a cultivar from which the lowest amount of oil was pressed but it was related to both husked and non-husked seeds.

\section{Conclusions}

Based on the analysis of the obtained results the following conclusions were made:

1. Analysis of research results allowed assessment of conditions and oil pressing performance between soya cultivars used for the research, their initial processing (husked and non-husked), applied head with a varied diameter of the opening and the course and performance of the oil pressing process.

2. The process of husking before pressing favourably influences the course and amount of the obtained oil causing increase of the amount of the obtained oil by approx. $20-30 \%$.

3. Out of seven soya cultivars used for the research, Pollux proved to be the most efficient (performance 11.01\%) and Mavka (9.88\%). This trend was maintained with pressing seeds of these cultivars on all heads of a device.

4. Protina was a cultivar from which the lowest amount of oil was pressed but it was related to both husked and non-husked seeds.

5. The pressing process duration was preconditioned with the presence of a seed shell. Oil pressing from the samples of husked seeds was considerably longer than in the oil pressing process from non-husked seeds. 
6. The amount of the obtained oil perceived as a laboratory performance of the screw press HYBREN type is preconditioned with three basic factors, i.e. presence or lack of fruitseed coat, cultivar-related differences of soya and the applied attachment with a varied diameter of an opening.

7. The obtained research results constitute a valuable foundation of practical data, which may be successfully used in industrial technologies of preparation and processing of seeds of various soya cultivars for food and fodder purposes.

\section{References}

Baler, G. (2013). Soja - roślina z przyszłością. Poradnik gospodarski, 9, 20-24.

Barowicz, T. (2008). Tłuszcz w paszy dla drobiu. Hodowca Drobiu, 134, 10-15.

Boros, L. (2002). Soja - charakterystyka odmian i technologia uprawy. Biuletyn IHAR 5, Radzików, 18-25.

Budzyński, W., Zając, T. (2010). Rośliny oleiste. Wyd. PWRiL, Poznań, ISBN: 978-83-09-99033-8.

Dłużewska, E. Krygier, K. (2005). Sojowe preparaty białkowe - otrzymywanie i zastosowania. Przemyst Spożywczy, 3, 30-35.

Domeracka, M. Soja. Źródło białka. Soja dla zwierząt, Soja dla ludzi. www.dodr.pl/IV/6/15/1.pdf.

Flowers, G., Ibrahim, S.A., Abu Ghazaleh, A.A. (2008). Milk Fatty Acid Composition of Grazing Dairy Cows When Supplemented with Linseed Oil. Journal of Dairy Science, 91, 722-730.

Łaska, B., Myczko, A., Golimowski, W. (2012). Badanie wydajności prasy ślimakowej i sprawności tłoczenia oleju w warunkach zimowych i letnich. Problemy Inżynierii Rolniczej, 4(78), 163-170.

Nowak, A. (2011). Nasiona soi zwyczajnej - cenny surowiec dietetyczny i leczniczy, Kosmos - Problemy Nauk Biologicznych, Tom 60, 1-2, 179-187.

Sikorski, E.Z. (2007). Charakterystyka białek głównych surowców żywnościowych. Chemia żywnościsacharydy, lipidy, biatka. Wydawnictwa Naukowo-Techniczne, Warszawa. ISBN: 978-83-2043629-7.

Zawadzki, K. (2010). Wykorzystanie mąki sojowej w produkcji pieczywa, Przegląd ZbożowoMtynarski, 2, 15-18.

\section{OCENA WYBRANYCH PARAMETRÓW TECHNICZNYCH PROCESU TLOCZENIA OLEJU Z NASION SOI}

Streszczenie. Celem pracy było określenie wpływu zmiennych wartości ciśnienia wytłaczania oleju metodą tłoczenia na zimno w prasie ślimakowej na przebieg i wydajność tłoczenia. Zróżnicowane wartości ciśnienia uzyskiwano poprzez zastosowanie trzech wymiennych końcówek zespołu tłoczącego o różnej średnicy kanału wylotowego $\left(\phi_{1}=2 \mathrm{~mm}, \phi_{2}=4 \mathrm{~mm}\right.$ i $\left.\phi_{3}=6 \mathrm{~mm}\right)$. Określano wydajność procesu tłoczenia oleju sojowego w zależności od zastosowanej końcówki oraz odmiany soi. Materiałem do badań były nasiona 7 polskich odmian soi niemodyfikowanej genetycznie. Wykazano, iż wpływ na efektywność wytłaczania mają zarówno zmienne wartości ciśnienia jak i wykorzystane odmiany soi. W oparciu o analizę uzyskanych wyników badań potwierdzono, iż zróżnicowane parametry techniczne i odmiany soi mają wpływ zarówno na wydajność tego procesu, jak i jego pozostałe parametry i warunki tłoczenia.

Słowa kluczowe: tłoczenie oleju, nasiona soi, parametry i warunki procesu, wydajność 